\title{
DETERMINANTS OF ROUTE PRESENCE IN THE EU AIRLINE INDUSTRY
}

\section{Ivana Tománková*}

\begin{abstract}
This paper investigates the determinants of airlines' route presence in the single EU aviation market by estimating two probit models - one for full-service airlines and one for low-cost carriers - which specify the presence (or absence) of an airline's service on the route as a function of its airport presence measures, the competition it faces from other airlines, and general route characteristics. The results point to the existence of dominant-firm advantages, domestic-firm privileges, and substantial airport-facilities-related barriers to entry in the EU airline industry. They further indicate that served routes are characterized by relative time efficiency of air travel (in comparison to car travel), large endpoint cities' populations as well as per capita GDPs; and that competitive effects between full-service and low-cost airlines are asymmetric.
\end{abstract}

Keywords: route presence, airline industry, air routes, airlines

JEL Classification: L93, R49

\section{Introduction}

Airline industries around the globe have undergone massive changes during the past few decades, turning from heavily regulated to highly dynamic. Liberalization of commercial passenger air transport in the European Union (EU) stands out as unique from among the series of deregulations that took place in other parts of the world, for it was not about one country deregulating its airline industry, but about creating a single aviation market, in which airlines licensed in one member state would be free to operate any route within the entire EU (Burghouwt et al., 2015).

The goal of this paper is to estimate the determinants of airlines' route presence (service) in the EU airline industry. Although the body of literature on the topics related to the airline industry is substantial, the vast majority of empirical studies rely on U.S. data. Their findings should not be adapted uncritically to the single EU aviation market as it represents a distinct institutional environment.

This paper is motivated by Berry's (1992) and Ciliberto's and Tamer's (2009) crosssectional studies of air route profitability, which employ an airline's presence on the route as an indicator of its profitability. However, certain developments in the airline industry, such as the network complementarities associated with extensive hub-and-spoke networks or the strategic considerations involved in the formation of airline alliances and mergers, have rendered the underlying assumption of these papers - that only profitable routes

Ivana Tománková, Faculty of Finance and Accounting, University of Economics in Prague, Prague,

Czech Republic (xtomi00@vse.cz).

The author is a Ph.D. student at the University of Economics in Prague, Prague. She would like to thank J. Lahvicka and the two anonymous reviewers for their comments. 
are served - highly contentious. For this reason, I investigate the determinants of airlines' route presence rather than route profitability. Naturally, since the factors determining route presence to some extent overlap with the factors determining route profitability, the model in this paper does bear some resemblance to the models employed in existing route profitability studies.

I construct two probit models - one for full-service airlines and one for low-cost carriers - that specify an airline's route presence as function of airline heterogeneity measures, airline competition, and route characteristics. I estimate these models using a sample of the EU's 31 busiest airports and 37 airlines.

The paper proceeds as follows. Section 2 provides an overview of existing literature on route profitability, barriers to entry, and airline competition. Section 3 presents variable construction and model specification. Section 4 describes the sample, while Section 5 reports and interprets the estimation results.

\section{Previous Work}

This paper relates closely to the route profitability studies of Berry (1992) and Ciliberto and Tamer (2009).

Berry (1992) investigates the role of an airline's airport presence (i.e. its share in airport's operations) in determining its route profitability. He monitors entry and exit decisions of the U.S. airlines after deregulation and constructs models that specify an airline's route presence as a function of firm and route characteristics. His results provide evidence that airlines enjoy certain advantages on routes originating from the airports they dominate. Borenstein $(1989,1991)$ lists naturally occurring information and reputation advantages, loyalty-promoting marketing instruments such as frequent flyer programmes, and bureaucratic control of airports' administrations as plausible sources of dominantfirm advantages. The importance of airport-facilities-related barriers to entry in the airline industry is illustrated by Berry's (1992) finding that an airline is more likely to serve a route if it has a near-zero airport presence at both its endpoint cities than if it has a $100 \%$ airport presence at one endpoint only.

Recent studies examine the effect of airport or route concentration on airfares rather than route presence. Bilotkach and Lakew (2014) find that concentration at the airport level is the most important determinant of airfares in the U.S. airline industry. With respect to entry barriers, Snider and Williams (2015) analyse the impact of AIR-21, an act that required highly concentrated U.S. airports to provide new entrants with eased access to airport facilities. They observe that airfares fell on average by $13 \%(20 \%)$ on routes with one (two) endpoint airport(s) directly affected by the legislation, mainly in response to new entry of low-cost carriers. Fare decreases for dominant airlines were particularly large, suggesting that the act eliminated the price premiums associated with airport dominance.

Ciliberto and Tamer (2009) expand Berry's work by taking into account face-to-face route competition. They show that competitive effects between airlines of different business types $^{1}$ are asymmetric: the profit-decreasing effect of low-cost entry on incumbent large

1 Basic business types in the airline industry include full-service airlines and low-cost carriers. Full-service airlines (FSAs) maintain extensive hub-and-spoke networks, providing a wide range of services that include pre-flight service, on-board service, flight scheduling to minimize airport waiting times, and baggage interlining between connecting flights (German Aerospace Center, 
airlines exceeds the effect of large-airline entry on incumbent low-cost carriers, which in turn exceeds the competitive effect between large airlines themselves. Furthermore, certain route characteristics influence the profitability of large airlines and low-cost carriers differently.

Table 1 | Findings of Selected Studies

\begin{tabular}{|c|c|c|c|}
\hline \multirow{2}{*}{ Dependent variable } & Berry (1992) & $\begin{array}{l}\text { Ciliberto and Tamer } \\
\text { (2009) }\end{array}$ & $\begin{array}{c}\text { Hernandez } \\
\text { and Wiggins (2014) }\end{array}$ \\
\hline & Route presence & Route presence & Airfares \\
\hline Population size & Positive effect & Positive effect & Negative effect \\
\hline $\begin{array}{l}\text { Product / income } \\
\text { per capita }\end{array}$ & - & Positive effect & Insignificant effect \\
\hline Airport traffic share & Positive effect & Positive effect & - \\
\hline $\begin{array}{l}\text { Presence at } \\
\text { both endpoints }\end{array}$ & Positive effect & - & - \\
\hline Tourist route & Positive effect & - & Negative effect \\
\hline Route distance & $\begin{array}{l}\text { First increasing, then } \\
\text { decreasing }\end{array}$ & $\begin{array}{l}\text { Positive effect for large } \\
\text { airlines, none for LCCs }\end{array}$ & Negative effect \\
\hline $\begin{array}{l}\text { Distance to } \\
\text { alternative airport }\end{array}$ & - & $\begin{array}{l}\text { No effect for large airlines, } \\
\text { positive for LCCs }\end{array}$ & - \\
\hline Route competition & - & $\begin{array}{l}\text { Negative effect; effect } \\
\text { of LCCs on large airlines } \\
>\text { effect of large airlines } \\
\text { on LCCs > effect between } \\
\text { large airlines }\end{array}$ & $\begin{array}{l}\text { Negative effect; effect } \\
\text { of Southwest > effect } \\
\text { of other LCCs }\end{array}$ \\
\hline Potential competition & - & - & $\begin{array}{l}\text { Negative effect } \\
\text { of Southwest, no effect } \\
\text { of other LCCs }\end{array}$ \\
\hline Adjacent competition & - & - & $\begin{array}{l}\text { Negative effect } \\
\text { of Southwest, no effect } \\
\text { of other LCCs }\end{array}$ \\
\hline
\end{tabular}

Source: Berry (1992), Ciliberto and Tamer (2009), Hernandez and Wiggins (2014)

Literature on the effects of airline competition and entry, particularly for low-cost carriers (LCCs) is abundant. Once again, however, these effects are assessed via variables other than route presence, such as airfares, market yields or flight frequencies. Alderighi et al. (2004) find that in response to low-cost entry, incumbent airlines reduce leisure as well as business fares, and that this effect is greater on monopolistic than on competitive

2008). Low-cost carriers (LCCs), by comparison, achieve lower costs by abandoning the free in-flight services, by serving simple point-to-point routes without flight connections or baggage interlining, and by taking advantage of uncongested, peripheral airports with lower aeronautical fees (German Aerospace Center, 2008). 
routes. Competition between full-service airlines (FSAs), by comparison, is associated with larger decreases in business class fares than in economy class fares. Hüschelrath and Müller (2011) compare the effects of FSA and LCC entry on market yields. The largest observed competitive effect is that of an LCC entering into a monopolistic route, followed by low-cost entry into an oligopolistic route. The competitive effects of FSAs are smaller, and there is no substantial effect for full-service entry into oligopolistic routes. Hernandez and Wiggins (2014) examine the competitive effects of Southwest Airlines and other U.S. low-cost carriers. In the case of Southwest, a fare-depressing effect is detected not only for direct onroute competition, but also for potential and adjacent competition, ${ }^{2}$ while the competitive effects of other LCCs are limited to face-to-face on-route competition. These results are in line with those of Goolsbee and Syverson (2008), who find that incumbent airlines cut airfares on the route when Southwest enters its second endpoint (yet not the route itself), as well as with Fageda's (2014) observation that low-cost competition from nearby secondary airports has no influence on the flight frequencies of FSAs.

Table 1 presents an overview of the effects estimated in three of the above mentioned studies, namely Berry (1992), Ciliberto and Tamer (2009), and Hernandez and Wiggins (2014). I select only those variables which will be relevant for the comparison of results with this paper's findings.

\section{Methodology}

To uncover the determinants of airlines' route presence, I specify a probit model where the binary dependent variable service ${ }_{i r}$, which indicates the presence (or absence) of a given airline $i$ on a given route $r$, is function of firm heterogeneity measures, competition variables and route characteristics.

Service $_{i r}=f$ (airport presence ${ }_{i r}$, airport $2_{i r}, F S A$ route competition ${ }_{i r}, L C C$ route competition $_{i r}$, FSA adjacent competition ${ }_{i r}$, LCC adjacent competition ${ }_{i r}$, FSA potential competition $_{i r}$, LCC potential competition $_{i r}$, distance, flight-to-driving time ${ }_{r}$, population ${ }_{r}$, GDP per capita ${ }_{r}$, tourist route ${ }_{r}$, domestic route ${ }_{i r}$, extranational route ${ }_{i r}$, airline identifiers ${ }_{i}$ )

Table 2 defines the variables.

As some variables may exert varying or even opposing effects with respect to airlines' business types, I estimate FSA and LCC versions of the model by restricting the sample to observations concerning only full-service or low-cost airlines.

Measures of airlines' airport presence are expected to positively affect route presence in line with Berry's (1992) findings. Airport presence proxies the extent of dominant-firm advantages, while airport 2 reflects airport-facilities-related sunk costs commitments airline $i$ has made on route $r$. Because sunk costs are a barrier to entry, an airline that has already made such commitments is more likely to serve the route.

Variables pertaining to competition are expected to depress service probability. The strength of competitive effects between FSAs and LCCs will reflect the extent of product differentiation and the aggressiveness with which these business types compete.

The oligopolistic nature of air routes raises endogeneity concerns for the variables FSA route competition ${ }_{i r}$ and $L C C$ route competition ${ }_{i r}$, since competitors' presence on route $r$

2 Potential competition refers to situations where entry into a route is highly probable due to the competing airline's presence at both endpoints of the route. Adjacent competition is generated by airlines that serve a given city-pair market, taking off from or landing at alternative nearby airports. 
not only affects, but is also affected by the presence of airline $i$ on the same route. Given that airport presence is a crucial determinant of route presence (Berry, 1992; Ciliberto and Tamer, 2009), I instrument these variables with the number of FSA / LCC competitors whose average airport presence on route $r$ exceeds the $5 \%$ threshold.

Table 2 | Variables' Definitions

\begin{tabular}{|c|c|}
\hline Service $_{\text {ir }}$ & Binary variable equal to one if airline $i$ serves route $r$ using its own aircraft. \\
\hline Airport presence $_{i r}$ & $\begin{array}{l}\text { Arithmetic mean of airline } i \text { 's airport presence at route }{ }^{3} \text { 's endpoints. } \\
\text { Airline } i \text { 's airport presence is calculated as the number of its aircraft } \\
\text { movements (takeoffs and landings) divided by the total number } \\
\text { of aircraft movements at the airport. Movements to route } r^{\prime} \text { 's other } \\
\text { endpoint are excluded. }\end{array}$ \\
\hline Airport2 & $\begin{array}{l}\text { Binary variable equal to one when airline } i \text { is present at both of route } \\
r \text { 's endpoints. }\end{array}$ \\
\hline $\begin{array}{l}\text { FSA route competition }{ }_{i r} \\
\text { LCC route competition }_{i r}\end{array}$ & $\begin{array}{l}\text { Number of FSAs / LCCs unaffiliated (via a merger or an alliance) with } \\
\text { airline } i \text { that operate on route } r \text {. }\end{array}$ \\
\hline $\begin{array}{l}\text { FSA adjacent competition }_{i r} / \\
\text { LCC adjacent competition }_{i r}\end{array}$ & $\begin{array}{l}\text { Number of FSAs / LCCs other than airline i operating alternative routes } \\
\text { to or from nearby airports that serve the same metropolitan area. }\end{array}$ \\
\hline $\begin{array}{l}\text { FSA potential competition } \\
\text { LCC potential competition }_{i r}\end{array}$ & $\begin{array}{l}\text { Number of FSAs / LCCs unaffiliated (via a merger or an alliance) with } \\
\text { airline } i \text { present at both route } r \text { 's endpoints but not serving route } r \text {. } \\
\text { To maintain the credibility of potential entry, I do not count airlines } \\
\text { that solely operate routes which connect to airports in their respective } \\
\text { countries of registration, unless route } r \text { is such route. }\end{array}$ \\
\hline Distance $_{r}$ & Flight distance between route r's endpoints, in thousands of kilometers. \\
\hline Flight-to-driving time, & $\begin{array}{l}\text { Route } r^{\prime} \text { s flight time (estimated for unserved routes) divided by its } \\
\text { driving time (includes ferry time in some instances). To account for fixed } \\
\text { time costs associated with air travel, I add an extra } 75 \text { minutes per large } \\
\text { airport }{ }^{4} \text { and } 50 \text { minutes per small airport to every route's flight time. }\end{array}$ \\
\hline Population $_{r}$ & $\begin{array}{l}\text { Geometric mean of route } r \text { 's endpoint populations, in millions } \\
\text { of inhabitants. }\end{array}$ \\
\hline GDP per capita $r$ & $\begin{array}{l}\text { Arithmetic mean of route } r \text { 's endpoints' gross domestic products } \\
\text { per capita, in thousands euros. }\end{array}$ \\
\hline Tourist route, & $\begin{array}{l}\text { Binary variable equal to one when at least one of route } r \text { 's endpoints } \\
\text { belongs to the nine most visited cities in the sample. }\end{array}$ \\
\hline Domestic route $_{i r}$ & $\begin{array}{l}\text { Binary variable equal to one if both route } r \text { 's endpoints lie within } \\
\text { airline i's country of registration. }\end{array}$ \\
\hline Extranational route $_{i r}$ & $\begin{array}{l}\text { Binary variable equal to one if both route } r \text { 's endpoints lie outside } \\
\text { airline i's country of registration. }\end{array}$ \\
\hline Airline identifiers & Set of binary variables to identify individual airlines. \\
\hline
\end{tabular}

3 For the purposes of this paper, a route is defined as a non-stop direct journey between two airports irrespective of direction.

4 Airports with over thirty million passengers in 2012 are classified as large. 
The inclusion of route characteristics is straightforward. Distance can proxy both demand and cost conditions. Flight-to-driving time inversely measures the time efficiency of air travel relative to car travel: the higher the ratio, the costlier in terms of time air travel is. Population, GDP per capita and tourist route proxy demand. Nevertheless, the effects of GDP per capita and tourist route may differ between FSAs and LCCs. If passengers regard low-cost travel as an inferior good, GDP per capita would decrease service probability for LCCs. A negative effect of tourist route is conceivable if FSAs surrender tourist routes to LCCs, which may cater better to price-conscious vacationists. The variables domestic route and extranational route capture airlines' tendency toward operating on such routes relative to routes that connect an airport in the respective airline's country of registration with one beyond the country's borders. More importantly, by controlling for routes outside an airline's country of registration, extranational route eliminates the effect of a "home airport" from airport presence, which is left to capture dominant-firm rather than domesticfirm advantages.

\section{Data}

The main source of data is flightradar24.com. I use this flight-tracking website to create a database of flights between February 24 and March 2, 2014, from which I derive variables related to airlines' route and airport presence. To my best knowledge, there were no notable disruptions to the EU aviation industry during this time period.

I obtain factual information about individual airlines and their business types from airlines' websites, the Centre for Aviation (CAPA), and routesonline.com. Eurostat is the source for figures on passenger statistics, population, GDP, and tourism. Distances as well as flight and car ride durations are retrieved from airmilescalculator.com and Google Maps.

Selection of airports is based upon the 2012 Eurostat passenger traffic statistics. Airports within the geographical area of the EU and its cooperating countries with more than ten million passengers in 2012 qualify for inclusion in the sample. The resulting network consists of 31 airports $^{5}$, ergo 465 potential air routes.

Selection of airlines is based on the number of routes they serve in the network. Excluding airlines with less than five routes served as well as non-EU airlines and airlines whose core business is not commercial passenger air transport leaves 37 airline brands in the sample; 20 of these are full-service and 17 low-cost. ${ }^{6}$

5 Airports included in the sample are (in order of the number of passengers served in 2012): London Heathrow, Paris Charles de Gaulle, Frankfurt, Amsterdam, Munich, Madrid, Rome, Barcelona, London Gatwick, Paris Orly, Zurich, Copenhagen, Palma de Mallorca, Vienna, Oslo, Düsseldorf, Manchester, Stockholm, Brussels, Dublin, Milan, Berlin, London Stansted, Lisbon, Helsinki, Geneva, Hamburg, Athens, Málaga, Nice, and Prague. Adjacent airports (relevant for the variable adjacent competition) include the London trio Heathrow, Gatwick and Stansted, and the Paris duo Charles de Gaulle and Orly. The nine most visited cities in the sample, which enter into the variable tourist route, are Palma de Mallorca, Paris, Nice, Brussels, Málaga, Berlin, Barcelona, Zurich, and Milan.

6 I classify airlines as FSAs if their respective websites, CAPA or routesonline.com describe them as "full-service" or if they are national flag carriers; and as LCCs if they are referred to as "low-cost", "budget" or "no-frills". One exception is Ireland's flag carrier Aer Lingus, which is categorized as an LCC as it has adopted a low-cost model for the European market to compete with Ryanair (German Aerospace Center, 2008). Full-service airlines included in the sample are Aegean Airlines, Air Berlin, Air Europa, Air France, Alitalia, Austrian Airlines, British Airways, Brussels Airlines, Czech Airlines, Edelweiss Air, Finnair, Iberia, KLM, KLM Cityhopper, Lufthansa, Lufthansa 
The 37 airline brands in combination with 465 potential air routes give rise to 17,205 airport-airline observations. Eliminating observations with no airport presence at either of a route's endpoints reduces the sample size to 13,095 observations.

Table 3 presents the sample's descriptive statistics.

Table 3 | Descriptive Statistics (13,095 observations)

\begin{tabular}{|c|c|c|c|c|c|c|}
\hline Variable & Unit & Mean & Median & Min & Max & Std. dev. \\
\hline Service $_{i r}$ & dummy & 0.060 & 0 & 0 & 1 & 0.238 \\
\hline Airport presence $_{i r}$ & percentage & 0.027 & 0.008 & $6.5^{*} 10^{-5}$ & 0.427 & 0.052 \\
\hline Airport2 $_{\text {ir }}$ & dummy & 0.422 & 0 & 0 & 1 & 0.494 \\
\hline FSA route competition $_{i r}$ & airlines & 0.727 & 1 & 0 & 4 & 0.803 \\
\hline LCC route competition $_{i r}$ & airlines & 0.647 & 1 & 0 & 5 & 0.759 \\
\hline FSA adjacent competition $_{i r}$ & airlines & 0.301 & 0 & 0 & 3 & 0.670 \\
\hline LCC adjacent competition $_{\text {ir }}$ & airlines & 0.245 & 0 & 0 & 5 & 0.653 \\
\hline $\begin{array}{l}\text { FSA potential } \\
\text { competition }_{i r}\end{array}$ & airlines & 0.459 & 0 & 0 & 4 & 0.643 \\
\hline $\begin{array}{l}\text { LCC potential } \\
\text { competition }_{i r}\end{array}$ & airlines & 1.423 & 1 & 0 & 5 & 1.150 \\
\hline Distance $_{r}$ & thousands km & 1.137 & 1.046 & 0.034 & 3.368 & 0.631 \\
\hline Flight-to-driving time & ratio & 0.361 & 0.286 & 0.117 & 3.953 & 0.305 \\
\hline Population $_{r}$ & $\begin{array}{l}\text { millions } \\
\text { inhabitants }\end{array}$ & 3.581 & 3.111 & 1.107 & 11.978 & 1.874 \\
\hline GDP per capita $_{r}$ & thousands euros & 38.791 & 37.700 & 19.800 & 75.157 & 10.478 \\
\hline Tourist route, & dummy & 0.561 & 1 & 0 & 1 & 0.496 \\
\hline Domestic route $_{i r}$ & dummy & 0.009 & 0 & 0 & 1 & 0.092 \\
\hline Extranational route $_{i r}$ & dummy & 0.810 & 1 & 0 & 1 & 0.392 \\
\hline
\end{tabular}

Source: own calculations; underlying data from flightradar24.com, airmilescalculator.com, Google Maps, and Eurostat

\section{Results}

Table 4 and Table 5 present the estimation results for full-service and low-cost airlines, respectively.

CityLine, Portugalia, Scandinavian Airline System, Swiss, and TAP Portugal. Low-cost airlines included in the sample are Aer Lingus, Alitalia CityLiner, Blue1, EasyJet, Eurowings, Flybe, Germanwings, Helvetic Airways, Iberia Express, Jet2, Monarch Airlines, NIKI, Norwegian Air Shuttle, Ryanair, Thomson, Transavia, and Vueling. 


\begin{tabular}{|c|c|c|c|c|}
\hline \multicolumn{5}{|c|}{ Dependent variable: service } \\
\hline Independent variable ${ }^{7}$ & Coefficient & $\begin{array}{l}\text { Standard } \\
\text { Error }\end{array}$ & $\begin{array}{l}\text { Marginal effect } \\
\text { at the means }\end{array}$ & P-value \\
\hline Constant & -2.00 & 0.47 & - & $<0.001^{* * *}$ \\
\hline Airport presence & 15.04 & 1.15 & 0.012 & $<0.001^{* * *}$ \\
\hline Airport2 & 0.694 & 0.123 & 0.001 & $<0.001^{* * *}$ \\
\hline FSA route competition & -0.114 & 0.140 & $-9.3 * 10^{-5}$ & 0.415 \\
\hline LCC route competition & -0.743 & 0.186 & -0.001 & $<0.001^{* * *}$ \\
\hline FSA adjacent competition & -0.503 & 0.146 & $-4.1^{*} 10^{-4}$ & $0.001^{* * *}$ \\
\hline LCC adjacent competition & -0.203 & 0.121 & $-1.66^{*} 10^{-4}$ & $0.093^{*}$ \\
\hline FSA potential competition & -0.118 & 0.102 & $-9.6^{*} 10^{-5}$ & 0.249 \\
\hline LCC potential competition & -0.090 & 0.055 & $-7.3^{*} 10^{-5}$ & 0.103 \\
\hline Distance & -0.832 & 0.134 & -0.001 & $<0.001^{* * *}$ \\
\hline Flight-to-driving time & -1.53 & 0.27 & -0.001 & $<0.001^{* * *}$ \\
\hline Population & 0.206 & 0.032 & $1.68^{*} 10^{-4}$ & $<0.001^{* * *}$ \\
\hline GDP per capita & 0.011 & 0.006 & $8.9^{*} 10^{-6}$ & $0.064^{*}$ \\
\hline Tourist route & -0.343 & 0.105 & $-3.2^{*} 10^{-4}$ & $0.001 * * *$ \\
\hline Domestic route & -0.04 & 0.30 & $-2.8^{*} 10^{-5}$ & 0.902 \\
\hline Extranational route & -1.72 & 0.24 & -0.018 & $<0.001^{* * *}$ \\
\hline Mean dependent variable & 0.060 & - & - & - \\
\hline McFadden $R^{2}$ & 0.690 & - & - & - \\
\hline Cases correctly predicted & $\begin{array}{r}7,409 \\
(96.8 \%)\end{array}$ & - & - & - \\
\hline Observations & 7,651 & - & - & - \\
\hline
\end{tabular}

$7 \quad$ For lucidity's sake I do not report the parameter estimates for airline dummies. Suffice to say, that most of them are statistically significant, implying that airline heterogeneity goes beyond the factors accounted for in the model. Excluding these control variables lowers goodness-of-fit measures, but does not alter the models' conclusions. 
Table 5 | Estimation Results for LCCs

\begin{tabular}{|c|c|c|c|c|}
\hline \multicolumn{5}{|c|}{ Dependent variable: service } \\
\hline Independent variable & Coefficient & $\begin{array}{l}\text { Standard } \\
\text { Error }\end{array}$ & $\begin{array}{l}\text { Marginal effect } \\
\text { at the means }\end{array}$ & P-value \\
\hline Constant & -1.44 & 0.40 & - & $<0.001^{* * *}$ \\
\hline Airport presence & 13.08 & 0.86 & 0.313 & $<0.001^{* * *}$ \\
\hline Airport2 & 1.088 & 0.094 & 0.044 & $<0.001^{* * *}$ \\
\hline FSA route competition & -0.049 & 0.131 & -0.001 & 0.710 \\
\hline LCC route competition & -0.166 & 0.133 & -0.004 & 0.213 \\
\hline FSA adjacent competition & -0.322 & 0.092 & -0.008 & $<0.001^{* * *}$ \\
\hline LCC adjacent competition & -0.122 & 0.079 & -0.003 & 0.123 \\
\hline FSA potential competition & -0.092 & 0.074 & -0.002 & 0.216 \\
\hline LCC potential competition & -0.093 & 0.044 & -0.002 & $0.036^{* *}$ \\
\hline Distance & -0.328 & 0.112 & -0.008 & $0.003^{* * *}$ \\
\hline Flight-to-driving time & -1.33 & 0.40 & -0.032 & $0.001^{* * *}$ \\
\hline Population & 0.115 & 0.027 & 0.003 & $<0.001^{* * *}$ \\
\hline GDP per capita & 0.008 & 0.004 & $1.95^{*} 10^{-4}$ & $0.050^{*}$ \\
\hline Tourist route & -0.141 & 0.093 & -0.003 & 0.130 \\
\hline Domestic route & -0.21 & 0.32 & -0.004 & 0.520 \\
\hline Extranational route & -0.939 & 0.093 & -0.046 & $<0.001^{* * *}$ \\
\hline Mean dependent variable & 0.060 & - & - & - \\
\hline McFadden $R^{2}$ & 0.457 & - & - & - \\
\hline Cases correctly predicted & $\begin{array}{r}5,190 \\
(95.3 \%)\end{array}$ & - & - & - \\
\hline Observations & 5,444 & - & - & - \\
\hline
\end{tabular}

To illustrate the variables' quantitative effects, throughout this section I will calculate the changes in service probability for the route between Amsterdam (AMS) and Paris Charles de Gaulle (CDG) under hypothetical scenarios. To begin with, the model correctly predicts that the Dutch flag carrier KLM serves the route (probability 83\%) while Transavia, a low-cost airline registered in the Netherlands, does not (probability $4 \%$ ).

\subsection{Results for Airport Presence and Barriers to Entry}

An airline's average airport presence is by far the single most important determinant of whether it serves a route for both full-service and low-cost airlines. A five percentage 
point increase in its average airport presence increases the probability of KLM's route service by 13 percentage points (to 96\%) and Transavia's by 10 percentage points (to 14\%).

The highly statistically significant parameter estimate for airport 2 confirms the existence of airport-facilities-related barriers to entry. Commenting on his results, Berry (1992) states that "moving from serving one city to serving both is estimated to have the same effect on profits as increasing average city output share by about 38\%" (Berry, 1992, p. 909). Adapted to this paper's results, the statement reads: moving from serving one airport to serving both is associated with an increase in service probability that is equivalent to an increase in average airport presence by 4.6 and 8.3 percentage points for full-service and low-cost airlines, respectively. ${ }^{8}$ Even though airport-facilities-related barriers to entry are much lower in the EU today than they were in the US back in 1980, they are far from negligible, considering that average airport presence in the sample is $2.9 \%$ for FSAs and $2.5 \%$ for LCCs. If KLM and Transavia were to secure non-zero airport presence at the CDG airport in addition to AMS, their probabilities of serving the AMS - CDG route would rise by 12 and 22 percentage points (to 95\% and 26\%), respectively. For Transavia, the change in service probability in response to moving from presence at one endpoint to presence at both endpoints is comparable to Goolsbee's and Syverson's (2008) estimate for Southwest (from $0.25 \%$ to $18.5 \%$ ) based on $1993-2002$ data.

\subsection{Results for Airline Competition}

I consider three kinds of airline competition: face-to-face on-route competition from unaffiliated airlines (route competition), competition from airports serving the same urban area (adjacent competition), and potential competition from unaffiliated airlines (potential competition).

As the number of competitors on the route is endogenously determined, I use instrumental variables to obtain more sensible estimates. Even so, in three out of the four possible business-type combinations, the competitive effect is statistically insignificant. The remaining one case shows that the presence of a low-cost competitor on the route significantly decreases service probability for full-service airlines. If an LCC were to commence operations on AMS - CDG, KLM's service probability would decline by 24 percentage points (to $59 \%$ ). ${ }^{9}$

These results generally resemble the findings of previous studies, such as that by Hüschelrath and Müller (2011), who find that entry by low-cost carriers (but not full-

$8 \quad$ These results suggest that entry barriers are almost twice as high for LCCs relative to FSAs. However, it is not clear whether this difference persists in real terms. Let us assume that an airline is willing to make sunk costs commitments to gain access to airport facilities up to the amount that it would have to pay for increasing its average airport presence by the number of percentage points indicated in the text. If the cost of increasing airport presence by one percentage point is roughly two times higher for FSAs than LCCs - perhaps as a result of larger aircraft use, higher labour costs or the provision of on-board services - then entry barriers in real terms do not differ between FSAs and LCCs. If, however, this difference in costs does not exist or is considerably smaller, then securing access to airport facilities is worth more to LCCs than FSAs.

9 This negative relationship between LCCs and FSAs could also emerge from the common existence of routes which, due to demand conditions, can only sustain low-cost service. However, this should not be the case as some 83 routes in the sample are operated solely by LCCs compared to 137 routes with exclusive full-service operations. 
service carriers) produces significant decreases in the market yields of incumbent airlines. Similarly to Ciliberto and Tamer (2009), I find the competitive effects of airlines to be specific to their respective business types; however, unlike them I do not find any evidence for statistically significant competitive effects of LCCs on FSAs' route presence nor between FSAs themselves.

Effects of adjacent competition are negative and statistically significant across all business type combinations except between LCCs. The relatively more significant effect of full-service competition on LCC service probability and the relatively less significant effect of low-cost competition on FSA service probability may be attributed to FSAs operating from central airports, and thus offering relatively easy-to-access flight services in comparison with LCCs, which tend to base their operations at peripheral airports. Were a full-service airline to begin operations on the route AMS - Paris Orly, an alternative route to AMS - CDG, KLM's service probability would drop by 15 percentage points (to $68 \%$ ) and Transavia's by 1 percentage point (to $3 \%$ ). In case of a low-cost entry onto the alternative route, KLM's probability would fall by 5 percentage points (to $78 \%$ ) with that of Transavia unaffected.

These results, however, do not conform to those from previous studies. In Ciliberto's and Tamer's (2009) paper, LCCs appear to be subjected to adjacent competition, while FSAs do not. Fageda (2014) finds no relationship between low-cost adjacent competition and flight frequencies of FSAs. Given the mixed evidence coupled with the fact that adjacent competition has generally been investigated as a secondary topic alongside other central research questions, this type of airline competition would merit an academic treatment of its own, particularly since competition from adjacent airports is likely to intensify as central airports hit capacity constraints.

A statistically significant effect of potential competition occurs only between low-cost airlines. Potential LCC entry is more threatening than FSA entry not only because LCCs' cost structures make them aggressive competitors, but also because, given their flexibility of operations within simple point-to-point networks, potential LCC entry appears particularly credible. An additional potential low-cost competitor would lower Transavia's service probability to $3 \%$.

The absence of an effect of low-cost potential competition on the service probability of FSAs is a puzzle, especially given the statistically significant relationships between these business types in route and adjacent competition. Turning to previous studies, Goolsbee and Syverson (2008) find that full-service incumbent airlines cut fares in response to potential competition from Southwest. Hernandez and Wiggins (2014) examine the impact of Southwest's and other LCCs' competition on nonlinear pricing strategies of fullservice airlines. For potential competition, they discover a statistically significant effect of Southwest and an insignificant effect of other LCCs, thus lending some support to the results of this paper.

\subsection{Results for Route Characteristics}

The majority of route characteristics accounted for in the model affect the probability of service for full-service and low-cost carriers in the same direction. On average, served routes are characterized by short distances, relative time efficiency of air travel in comparison to car travel, and large endpoint populations as well as per capita GDPs. In addition, routes 
to or from tourist destinations are on average less likely to be served by an FSA, suggesting that FSAs tend to relinquish tourist routes. I encourage the reader to refer back to Table 1 for a comparison of results with previous studies.

Coefficients for domestic route and extranational route reveal that airlines, fullservice as well as low-cost, are significantly less likely to serve routes entirely outside their respective countries of registration, despite being granted legal access to any route within the EU aviation market. The effect is substantial: were the AMS - CDG route entirely outside of the Netherlands neither Transavia nor KLM would serve it (respective probabilities 0\% and 17\%). The existence of domestic-firm advantages may arise from historical development or preferential treatment by authorities (airports, governments) or even by consumers who prefer travel with "their" national airline. In addition, flag carriers continue to be bound to their respective national airports due to restrictions on operating routes to countries outside of the EU (Burghouwt, 2015).

\section{Conclusion}

Existing literature investigates route presence determinants in the deregulated U.S. airline industry; yet the single EU aviation market represents an institutionally unique environment. The purpose of this paper has been to establish whether the findings derived from U.S. data also apply to the EU airline industry.

I perform the analysis on a sample of 31 airports and 37 airlines. I estimate two probit models, one for full-service airlines and one for low-cost carriers, which specify an airline's presence (service) on the route as function of its airport presence measures, airline competition, and route characteristics.

The results show that airport presence is the single most important determinant of airlines' route presence, suggesting that dominant-firm advantages matter considerably. Airport-facilities-related barriers to entry are much lower in the EU nowadays than they were in the US back in the 1980s and, for low-cost carriers, comparable to what they were in the 1990s. However, they are not negligible: gaining access to a route's second airport is in terms of the impact on service probability equivalent to an increase in average airport presence by 4.6 and 8.3 percentage points for full-service and low-cost airlines, respectively. Further research is required to validate this difference in entry barriers between airline business types and to determine its causes.

Airline competition estimates point to asymmetric effects between full-service and low-cost airlines. The presence of a low-cost competitor significantly decreases the service probability of a full-service airline operating on the same route. And while full-service airlines are fierce adjacent-airport competitors, considerably lowering the service probability of low-cost carriers as well as of other full-service airlines, statistically significant potential competition occurs solely among low-cost carriers. Some of these results, in particular those for potential and adjacent competition do not wholly conform to existing U.S. studies, indicating that competitive interactions between airline business types may be regionally specific.

On average, served routes are characterized by short distances, relative time efficiency of air travel in comparison to car travel, and large endpoint populations as well as per capita GDPs. In addition, routes to popular tourist destinations are less likely to be served by full-service airlines than non-tourist routes. Despite EU airlines' permission to operate any 
route within the territory of its member states, routes that lie entirely outside an airline's country of registration are significantly less likely to be served relative to routes with one or both endpoints in that airline's home country. It is evident that domestic-firm advantages as well as traffic restrictions imposed by agreements with third countries prevent the full exploitation of the freedoms of the air granted to EU airlines.

This paper's value added consists in extending the research on the determinants of airlines' route presence to encompass the EU aviation market as well as potential competition. In addition to supporting the previously estimated qualitative results for airport presence and providing somewhat divergent evidence on the competitive effects between airline business types, this paper's results indicate that airport-facilities-related barriers to entry may differ between full-service and low-cost airlines, and that domesticfirm advantages persist in the single EU aviation market.

\section{References}

Alderighi, M. et al. (2004). The Entry of Low-Cost Airlines: Price Competition in the European Airline Market. Tinbergen Institute Discussion Paper No. TI 04-074/3.

Berry, S. T. (1992). Estimation of a Model of Entry in the Airline Industry. Econometrica, 60(4), 889-917.

Bilotkach, V., Lakew P. A. (2014). On Sources of Market Power in the Airline Industry: Panel Data Evidence from the US Airports. Transportation Research Part A: Policy and Practice, 59, 288-305. DOI: 10.1016/j.tra.2013.11.011.

Borenstein, S. (1989). Hubs and High Fares: Dominance and Market Power in the U.S. Airline Industry. The RAND Journal of Economics, 20(3), 344. DOI: 10.2307/2555575.

(1991). The Dominant-Firm Advantage in Multiproduct Industries: Evidence from the U.S. Airlines. The Quarterly Journal of Economics, 106(4), 1237-1266. DOI: $10.2307 / 2937963$.

Burghouwt, G. et al. (2015). EU Air Transport Liberalisation: Process, Impacts and Future Considerations. International Transport Forum Discussion Paper No. 2015-04.

Ciliberto, F., Tamer, E. (2009). Market Structure and Multiple Equilibria in Airline Markets. Econometrica, 77(6), 1791-1828. DOI: 10.3982/ECTA5368.

Fageda, X. (2014). What Hurts the Dominant Airlines at Hub Airports? Research Institute of Applied Economics Working Paper 2014/14.

German Aerospace Center (2008). Airline Business Models. Köln: German Aerospace Center.

Goolsbee, A., Syverson, S. (2008). How Do Incumbents Respond to the Threat of Entry? Evidence from the Major Airlines. The Quarterly Journal of Economics, 123(4), 1611-1633.

DOI: 10.1162/qjec.2008.123.4.1611.

Hernandez, M. A., Wiggins, S. N. (2014). Nonlinear Pricing Strategies and Competitive Conditions in the Airline Industry. Economic Inquiry, 52(2), 539-561. DOI: 10.1111/ecin.12045.

Hüschelrath, K., Müller, K. (2011). Patterns and Effects of Entry in US Airline Markets. Centre for European Economic Research ZEW Discussion Papers No. 11-059.

Snider, C., Williams, J. W. (2015). Barriers to Entry in the Airline Industry: A Multi-Dimensional Regression-Discontinuity Analysis of AIR-21. Review of Economics and Statistics, 97(5), 1002-1022. DOI: 10.1162/REST_a_00455. 